\title{
Hisbah (Ombudsmen) is A Mechanism for Resolving Enforcement Issues in Malaysia: Changes and Difficulties
}

Nur Sarah Tajul Urus, Md. Amin Abdul Rahman Al-Jarumi, Mohd Syahmil Samsudin, Mus'ab Yusoff

To Link this Article: http://dx.doi.org/10.6007/IJARBSS/v12-i1/12256

DOI:10.6007/IJARBSS/v12-i1/12256

Received: 09 November 2021, Revised: 13 December 2021, Accepted: 03 January 2022

Published Online: 27 January 2022

In-Text Citation: (Urus et al., 2022)

To Cite this Article: Urus, N. S. T., Al-Jarumi, M. A. A. R., Samsudin, M. S., \& Yusoff, M. (2022). Hisbah (Ombudsmen) is A Mechanism for Resolving Enforcement Issues in Malaysia: Changes and Difficulties. International Journal of Academic Research in Business and Social Sciences, 12(1), 1933-1941.

Copyright: (C) 2022 The Author(s)

Published by Human Resource Management Academic Research Society (www.hrmars.com)

This article is published under the Creative Commons Attribution (CC BY 4.0) license. Anyone may reproduce, distribute, translate and create derivative works of this article (for both commercial and non0-commercial purposes), subject to full attribution to the original publication and authors. The full terms of this license may be seen

at: http://creativecommons.org/licences/by/4.0/legalcode

Vol. 12, No. 1, 2022, Pg. 1933- 1941

Full Terms \& Conditions of access and use can be found at http://hrmars.com/index.php/pages/detail/publication-ethics 


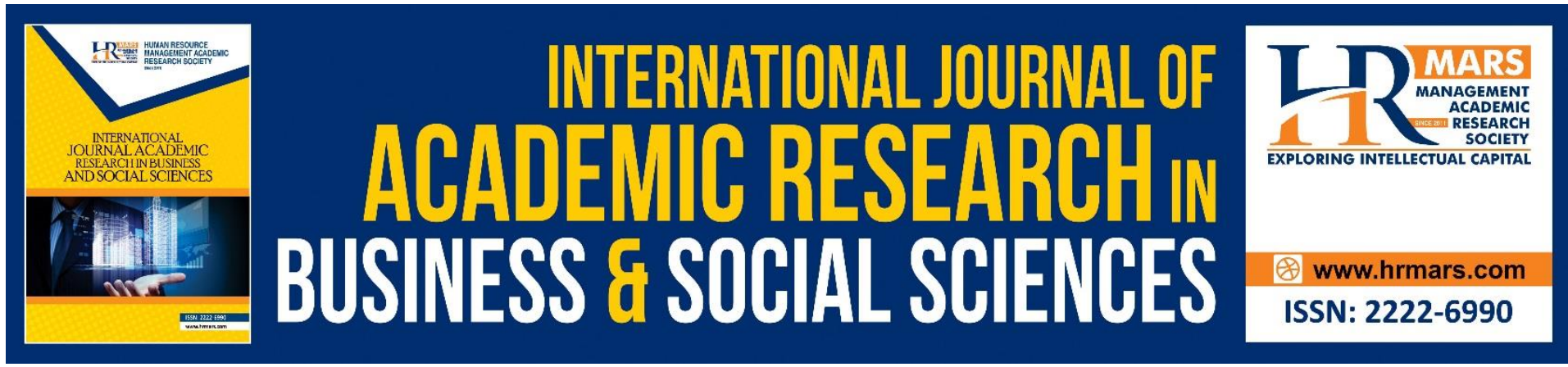

\title{
Hisbah (Ombudsmen) is A Mechanism for Resolving Enforcement Issues in Malaysia: Changes and Difficulties
}

\author{
Nur Sarah Tajul Urus ${ }^{1}$, Md. Amin Abdul Rahman Al-Jarumi², \\ Mohd Syahmil Samsudin ${ }^{3}$, Mus'ab Yusoff ${ }^{4}$
}

${ }^{1}$ Lecturer at Kulliyyah Syariah and Laws, Sultan Abdul Halim Mu'adzam Shah, International Islamic University (UniSHAMS), ${ }^{2}$ Professor at Kulliyyah Syariah and Laws, Sultan Abdul Halim Mu'adzam Shah, International Islamic University (UniSHAMS), ${ }^{3}$ Lecturer at Kulliyyah Syariah and Laws, Sultan Abdul Halim Mu'adzam Shah, International Islamic University (UniSHAMS).

${ }^{4}$ Lecturer at Kulliyyah Syariah and Laws, Sultan Abdul Halim Mu'adzam Shah, International Islamic University (UniSHAMS).

Corresponding Author: nursarah@unishams.edu.my, aminaljarumi@unishams.edu.my, syahmil@unishams.edu.my,musab@unishams.edu.my

\begin{abstract}
Religious enforcement officers require a more sophisticated and competitive paradigm change in order to improve the credibility and image of Islamic religious organizations. To summarize, the hisbah exists in Islamic philosophy, but there is no practice in our country, such as the shariah police, which functions as an advocacy group for the Syariah Court. This article is based on doctrinal research that extensively depends on relevant Islamic concepts contained in the Quran, Sunnah, and other sources of Islamic knowledge. The goal of this study is to identify and investigate hisbah in a Malaysian context. The purpose of this essay is to identify and examine hisbah in a Malaysian setting. The Hisbah in question is a governmental religious enforcer. As a result, there are advantages and disadvantages that should be improved in the future.
\end{abstract}

Keywords: Hisbah, Execution.

\section{Introduction}

Hisbah is a concept that tries to enhance everyday life discipline by using guidance as a guide and making changes based on community corrections (social correction) to faults committed. The original concept of the hisbah is made up of two major components: Amar makruf and Nahi Munkar. The Quranic verses connect the notion of the hisbah to the portrayal of a Muslim as the best of people (khayr ummah), because one of the few conditions of khayr ummah is that persons who dare to call others to do good and honestly prevent others from doing evil. In a moderate community, Amar makruf, or urging people to do good, is greatly promoted. However, if disobedience is shown to be pervasive in a community, the efforts of nahi mungkar must take precedence over the efforts of amar makruf. The hisbah exists in Islamic philosophy, but there is no practice in Malaysia. The purpose of this research is to 
identify and examine hisbah in a Malaysian setting. The Hisbah in question is a governmental religious enforcer - there are advantages and disadvantages that should be improved.

\section{Research Methodology}

This article employs a completely qualitative approach. Most library-sourced products that are based on published materials, such as textbooks, journal articles, online databases, and the Internet, employ content analysis modes as well. The study employs a unique style of data analysis, namely a descriptive, critical, and comparative approach (Ahmad \& Jamalullail, 2017).

\section{The Historical Beginnings of Hisbah}

During the reign of the Abbasid Caliphate, a Hisbah department was founded, along with the appointment of the first full-time muhtasibia. Authority is the same as that granted to the police, but solely against the Syariah Criminal Offences Act/Enactment. Code of ethics is a guideline developed to ensure Sharia law enforcement is done in a more ethical, disciplined, and in accordance with the needs of the law. This code is supposed to be standardized at the state level, and to more efficiently, openly, and effectively lift the concept of al-amr bil makruf wa nahyu anil munkar.

Based on historical circumstances, the Prophet PBUH appointed several muhtasib, notably Said ibn al-'As in Mecca and Umar bin al-Khattab in Medina. Aside from that, there are mutatawi' (volunteers) who work to guarantee that amar makruf is practiced. This tradition was followed after the Prophet PBUH's rule by the Caliphs of Ar-Rasyidin. Due to the expansion of the Islamic empire and the growing number of Muslims, the Caliphs have also expanded the number of muhtasibs. During the medieval period, many everyday activities are carried out around the clock in marketplaces, workshops, mosques, public baths (hammams), clubs, caravanserai (hotels), and so on in the city center.

Muhtasib is in charge of policing public behavior in order to prevent fraud, extortion, and other crimes. Of course, such a duty need a Shariah-compliant rule and regulation. During the reign of the Abbasid Caliphate, the Abu Jaafar al-Mansur era, which lasted from 136 Hijrah to 158 Hijrah, or 754 AD to 775 AD, a Hisbah department was founded, along with the appointment of the first full-time muhtasib (Zubaidah, 2018).

During the reign of Caliph al-Mahdi, it was also said that a more organized department was established. Historically, muhtasib did not spend much time in the office, preferring to undertake patrols and surveillance in market places where conflicts over scales, measures, and sales and contracts are common. The hisbah's scope and functions also include overseeing Friday prayers, mosque upkeep, and a variety of public problems.

Ibn Taymiyyah was one of the first to explain the purpose of the hisbah as a formal organization with regulations to guarantee social harmony and conformity with the laws. According to Ibn Taimiyah, Hisbah is a moral as well as a socioeconomic organization in which civil society life may be organized when high public morality is emphasized and society is safeguarded from fraud, abuse, energy, and so on. 
Al-Ma'alim al-Qurba is a muhtasib handbook written by Ibn al-Ukhuwah that thoroughly describes the roles, functions, and methods of operations to assist the muhtasib duty in Egypt at the time. Through his essay, Risalah fi Adab al-Hisba wa al-Muhtasib, an Andalusian author called Ahmad b. 'Abd Allah b. 'Abd al-Ra'uf, directs the muhtasib to inspect hammam and caravanserais during Friday prayers to ensure that no one attempts to escape conducting Friday prayers. This is significant because civil society cannot move beyond the advising and warning method to amar makruf nahi mungkar. They are not permitted to arrest or enter any premises at their discretion.

\section{Federalism and Enforcement}

Malaysia is a federal state with one federal government and thirteen (13) state governments, each having its own executive body, parliament, and syariah judiciary. In addition to courts, enforcement units, prosecutions, and sharia attorneys play major roles in the administration of sharia criminal justice, where they are selected individually according to the administration of their different states.

In civil courts, the primary enforcement teams, the police force, the prosecution team, advocates, and solicitors are all from the same federal administration. Other federal states or organizations, such as Australia and the United States, have independent enforcement agencies to execute their domestic authorities.

In certain cases, federal law enforcement will enforce federal law, while state law enforcement will implement state laws. In Malaysia, the situation is the polar opposite. There are no similar enforcement bodies at the state level, and police forces are put under federal service. The state, on the other hand, has its own Sharia enforcement unit. This enforcement entity is given the authority to conduct investigations, interrogations, arrests, and detentions of suspects or witnesses (Suffian, 2015).

Sharia enforcement groups, on the other hand, still require the assistance of the police department, which serves as the primary enforcement body. Furthermore, because sharia enforcement organizations cannot carry firearms, and enforcement officials are not immune from physical attacks by the investigated parties, the participation of the police force is required in order to carry out efficient enforcement operations. In truth, assisting state sharia enforcement organizations is not a concern because police forces have a duty to implement the Police Act and other "laws." According to the Federal Constitution, "law" incorporates both federal and state law (Jamal, 2017).

\section{Syariah Enforcement In Accordance With Current Laws And Regulations}

Religious enforcers are sharia criminal law enforcement agencies that work under the supervision of their respective State Islamic Religious Departments. The legal authority afforded to religious authorities is the same as that granted to the police, but solely against the Syariah Criminal Offences Act/Enactment and other Islamic legislation, such as the ability to arrest, search, seize, summon, and interrogate witnesses. The investigation's findings will be presented to the shariah court by the Syariah prosecutor. Religious enforcement powers, on the other hand, are restricted to the states that appoint them and cannot cross state lines. The same is true for the authority to summon witnesses from other lands to testify in that land. Witnesses from foreign states cannot be compelled to testify by religious authorities. Sharia courts have exclusive authority over Muslims, according to the requirements of the 
Federal Constitution in item 1, The State List in the 9th schedule. This means that nonMuslims are not subject to the punishments of Sharia courts. Based on the existing reality, the clause makes it difficult to enforce against non-Muslims in situations such as khalwat, the dissemination of false dakyah, cults, non-Muslim insults to Islam, or aiding and abetting the commission of sharia criminal crimes. As a result, sharia law enforcement is less efficient because non-Muslims cannot be charged or sentenced to criminal punishment by sharia courts.

\section{Islamic Religious Enforcement Officers' Authority and Jurisdiction}

The above topic was explored in light of Malaysia's Enactment on the Control of the Expansion of Non-Muslims to Muslims. The Constitution permits state legislatures to impose Islamic law within the restrictions established by the Constitution, and is subject to federal legislation that also mandates complete application of Islamic law.

Following that, the PPA's source of authority in this Control Enactment begins with Article 3, is followed by Article 11 (4) of the Federal Constitution, and is legislated by the Control of States Enactment.

The appointment of the PPA or the official authorized to execute out the applicable enactments is in conformity with the Heads of Islamic Religion in those governments where the term Sultan is used, such as Kedah, Kelantan, Pahang, Johor, Terengganu, Selangor, and Perak are just a few examples. Perlis, on the other hand, used the title Raja. However, when contrasted to the appointment of PPA under the State Islamic Religious Administration Enactment, this step of appointment demonstrates the significance and size of the responsibility of those appointed. This circumstance reflects a broader area of activities and jurisdiction.

In contrast to the State Islamic Religious Administration Enactment, this Control Enactment allows those appointed to arrest both Muslims and non-Muslims who make mistakes, as opposed to the widely held belief in the community that arrests can only be made against Muslims, as the State Islamic Religious Administration Enactment does. Except for Kedah, all states having this Control Enactment have appointed 'Public Officials' to 'Officers in the State Civil Service' as authorized officers. The position of Public Officers is public, which includes anybody who can be appointed from among government officials such as police, religious officers, the Ministry of Home Affairs, and others.

The scope is broader, so it no longer applies just to state government officials, but also to federal government officials. Kelantan, Negeri Sembilan, Pahang, Johor, Melaka, Terengganu, Selangor, Perak, and Perlis are the states involved. The position of 'Officers in the State Civil Service' is unique in that it is only available to civil officials appointed by the state government and is not available to federal civil workers. There are two types of titles for individuals appointed in the legislation of control of these states. The term 'Certified Officer' is used in Kelantan, Melaka, Terengganu, Selangor, Kedah, and Perlis. Meanwhile, the titles 'Authorized Officer' are used in Negeri Sembilan, Pahang, Johor, and Perak (Yahya et al., 2019).

\section{Appointment Of A Religious Enforcement Officer (PPA)}

All Religious Enforcement Officers (PPA) are government personnel appointed within the Religious Officer/Islamic Affairs Officer program. Their nomination to the PPA role is to fill 
open slots. As a result, when a job vacancy arises as a result of a transfer, promotion, or other procedure, an officer who is currently serving as a Zakat Officer or Da'wah may be appointed to assume the post of PPA. Existing PPA will also be shifted to another section if there is a promotion procedure to a higher grade or openings in other sections. The 'disadvantage' is that this procedure sometimes requires skilled PPA. A newly appointed PPA would undoubtedly require some time to adjust to and comprehend the complexities of new obligations. As is commonly known, enforcement actions are based on both complaints and operations. PPA, for example, has to understand how a complete investigation should be carried out in order to carry out the investigation process. Inexperienced or untrained cops will almost certainly wind up in a dead-end if they are not given leadership and direction (Ismail, 2008).

\section{Laws And Regulations Relating To Enforcement}

The Standing Order of the Director of the State Islamic Religious Department 2007, the Code of Ethics of State Islamic Religious Department Religious Enforcement Officers 2008, and the Chief Syariah Prosecutor Directive 2011 are among the rules and regulations. These instructions are directions for enforcing Sharia criminal law given by JAKIM's Law Enforcement Coordination Division as a consequence of JAIN's collaborative efforts throughout Malaysia.

\section{Standing Instruction Of The Director Of The State Islamic Religious Department In 2007}

This standing Instruction is an explanation and explanation to the Acts/Enactments/Syariah Criminal Procedure Ordinances in force in their respective states. It is an administrative directive that all PPA should consult and follow when doing their jobs. This directive is divided into several sections: the precedent, the procedure for receiving information, the procedure for conducting investigations, the procedures for preparing investigation papers, the preparation of case reports, the handling of seized goods, the general, and the first schedule relating to the proposed contents of the investigation paper.

\section{Code Of Ethics For State Islamic Religious Enforcement Officers In 2008}

This code of ethics is a guideline developed to guarantee that Sharia law enforcement is done in a more ethical, disciplined, and in accordance with the needs of the law, as well as in accordance with the requirements of Islamic law. Furthermore, this code is supposed to be standardized at the state level, as well as to more efficiently, openly, and effectively lift the concept of al-amr bil makruf wa nahyu anil munkar. This Code is divided into numerous sections, including name parts, application, general code of conduct, particular code of conduct, and general parts. The general and particular sections of the Code of Conduct are an important aspect of this code. The General Code of Conduct specifies the Code of Conduct standards that should be in place at each PPA prior to carrying out tasks in everyday life and during the service time as a PPA. While the specific code of conduct is connected to the code of conduct that should exist in each PPA in the course of the tasks of al-amr bil makruf wa nahyu anil munkar.

\section{Directives From the Chief Syariah Prosecutor}

This instruction is a guideline for all Syariah Prosecutors in Malaysia to follow while prosecuting Sharia law. This instruction was agreed upon by the Meeting of Malaysia's Chief 
Religious Enforcement and Chief Syariah Prosecutor, as well as the Conference of Malaysia's Heads of Departments/State Islamic Religious Councils.

This directive is divided into eight (8) sections: the initial part, the preparation of register books and record books, the acceptance and revision of investigation papers, the principles of prosecution, the preparation of charges, the prosecution and trial proceedings, the appeals, and the general divisions. In general, the majority of these directives pertain to a Syariah Prosecutor rather than a PPA. However, several provisions in this directive should be followed by PPA, including the record of submission and receipt of investigation papers from the Enforcement Division, review of the investigation papers from the perspective of the investigation order from the Chief Enforcement Officer, the PPA information form, and the PPA investigation report. When a complaint is received, PPA will enforce the law. Such objections can be submitted by anybody who is aware of immorality and is opposed to Sharia rule. Complaints will be kept secret and will not be made public. Complaints can be made in writing or verbally. Complainants can come to the Enforcement Division and fill out the complaint form in person. Furthermore, complainants have the option of filing a formal complaint (Farok, 2017).

\section{Difficulties in Enforcement}

\section{i. Personnel Scarcity, Expertise, And Training}

Staff shortages are prevalent and frequently faced in any law enforcement department. In certain districts, the number of enforcement division employees is insufficient to carry out the mission of preventing and regulating defaults, let alone lowering the rate of Syariah crime connected to morality, faith, and so on. This is in addition to the transfer of workers to other areas once they have been taught and become adept in carrying out operations, investigations, and legal knowledge. PPA includes Islamic Affairs Officers (S48/41), Assistant Islamic Affairs Officers (S27-32) and the majority of Islamic Affairs Assistants (S17).

The Islamic Affairs Officer has a degree in Islamic Studies, and the workers in grades S27 to S17 have degrees or certificates. Enforcement tasks are law-oriented, which means that they must comprehend Sharia law, processes, and other topics relevant to their duties in order to satisfy the requirements of the investigation and enforcement duties of Syariah criminal crimes, according to the given jurisdiction. Sections 68(1) and 68(3) of the Perak Islamic Religious Administration Enactment, for example, are likewise accessible in other states. As a result, training in legal comprehension is essential. It would be undesirable if these officers and personnel were advised to do their tasks without receiving advanced training (either intensely or on a regular basis) as soon as they were on the job.

As a result, training should be planned so that each PPA on duty understands the requirements of their tasks and each applicable legislation and work regulation. This can eliminate criticism and concerns about threats received by the suspect, excessive questioning time, charges of delivering disrespectful words to the suspect, accusations of spying, accusations of collecting bribes, and a slew of other claims leveled at PPA. Each state's Islamic religious department may be able to collaborate with the central agency to develop a comprehensive training curriculum to empower PPA.

ii. Uncertainty in Legal Provisions

There are around 45 provisions for offenses under Sharia criminal law in general, which include offenses linked to faith, morals, the sanctity of Islam, and many more. When fine- 
tuned, it discovered approximately 20 faults that were not obvious components of his guilt. As a result, PPA frequently confronts obstacles and difficulties when carrying out law enforcement activities and conducting operations. For example, there is an act considered to be an offence under an offence of disrespect, as explained in section 57 of the Perak Criminal Enactment (Syariah) 1992: "Any person who commits an act or behaves indecently in any public place contrary to The Law of Syara' shall be guilty of an offence and shall, on conviction, be punished." It is difficult to execute regulations like the one above since there are no clear and reasonable criteria on what constitutes "anyone" and "disrespectful behaviour." Although the JKSM Practice Directive from 2005 said that disrespectful behaviors include clothes and behavior, the needed element of disrespect is also quite subjective. As a result, section 56 is viewed as targeting only women who dress up, revealing unsuitable limbs to the point that it may pique the interest of those who observe, and the legislation is criticized of being unjust to women.

iii. The lack of a material storage facility

During the enforcement and arrest procedure, the authorities should seize the objects involved in the arrest so that they may be utilized as evidence in court and bolster the prosecution's case. However, among the things confiscated are those that are perishable and not long-lasting. When the objects in this case begin to deteriorate or expire, the prosecution procedure is hampered and questions are raised. During a raid on an entertainment establishment, for example, there were Muslim visitors who consumed alcohol. The booze bottles will be confiscated as evidence by the Religious Authority. However, because the Enforcement Division lacks a specific area or refrigerator for storing the bottles, it is not impossible.

\section{iv. Officers Who Change Positions Frequently}

The issue of shifting officials at the Islamic Religious Department is a limitation that frequently hinders the movement or journey of matters in the Enforcement Division. Because this Enforcement Division is housed with other old components of the State Islamic Religious Department component, it is also engaged in the case of a divisional exchange. Many religious enforcers expressed their dissatisfaction with this scenario, believing that altering sections was causing issues. For example, if a long-serving Religious Enforcement Officer in the Prosecution Division is transferred to the Mosque Division, his investigative, arresting, and intelligence talents will be rendered ineffective and undeveloped. As more policemen were assigned to the Enforcement Division, the situation got complicated. The absence of experienced officers frequently causes issues with the enforcement division's procedural execution. Officers in the Enforcement Division should be kept in the Enforcement Division to handle this issue. If the officers need to be replaced, the swap should take place in the Enforcement Division's field of assignment (Azhar, 2018).

\section{Conclusion}

In conclusion, while there are legal requirements and enforcement against them, there is still a gap in some areas that must be rectified. This is because the enforcement body must be viewed as a powerful and solid institution in the overall implementation of justice.

\section{Acknowledgment}

The International Islamic University Sultan Abdul Halim Mu'adzam Shah (UniSHAMS) funded the research with a University Research Grant (GPU) from 2018 to 2020. 


\section{Corresponding Author}

Nur Sarah binti Tajul Urus

Lecturer, Kulliyyah of Syariah and Law, Universiti Islam Antarabangsa Sultan Abdul Halim Mu'adzam Shah (UniSHAMS), Malaysia.

Email: nursarah@unishams.edu.my

\section{References}

Azhar, A., Badarulzaman, M. H., Hussain, M. A., Noor, F. M. (2018), Parameter Hisbah Dalam Kerangka Perundangan Jenayah Syariah Di Malaysia, International Journal of Law, Government and Communication, Volume: 3 Issues: 9, h. 49, www.ijlgc.com. di www.jurnalumran.utm.my/index.php/umran.

Shuaib, F. S. (2015), Isu Perlembagaan dan Hak Asasi Manusia dalam Pentadbiran Keadilan Syariah, Jurnal Kanun, hh. 42-43, di http://irep.iium.edu.my

Jamal, J. (2017), Ulasan Buku Penguatkuasaan Undang-undang Jenayah Islam di Malaysia yang ditulis oleh Shamrahayu A. Azi, Jurnal Kanun, hh. 131-132, di http://jurnalkanun.dbp.my.

Nor, M. F. M., Hassim, M. H., Ab Hamid, N. A., Rashid, A. M., Salleh, M. (2017), Skop dan Peranan Badan Penguatkuasa Syariah Negeri Sarawak: Kupasan dan Cadangan Penambahbaikan, 4 th International Research Management \& Innovation Conference (IRMIC 2017) Institut Latihan Malaysia (ILIM) Bangi, hh. 241-242 di http://rmc.kuis.edu.my.

Ismail, S. Z. (2008), Dasar Penguatkuasaan dan Pendakwaan Syariah di Malaysia: Satu Analisis, Jurnal Syariah, Jil. 16 Keluaran Khas, h.544, di www.researchgate.net.

Ismail, S. Z. (2018), Penguatkuasaan VS. Dosa Peribadi, h. 4, Kertas Kerja ini dibentangkan di Konvensyen Pegawai Penguatkuasa Agama dan Pendakwa Syarie Seluruh Malaysia bertempat di Hotel Copthorne, Pulau Pinang.

Ismail, S. S., Yusof, Z., Azahari, M. A. A.M. (2014), Cabaran Perundangan Penguatkuasaan dan Pendakwaan Syarie: Tumpuan Terhadap Tatacara Penguatkuasaan dan Pendakwaan Jenayah Syariah, Jurnal Hukum, bil. 4, h. 170, www.researchgate.net.

Yahya, Z., Samuri, M. Al A. (2019), Punca Kuasa dan Bidang Kuasa Pegawai Penguatkuasa Agama Islam Berkaitan Enakmen Kawalan Pengembangan Agama Bukan Islam Kepada Orang Islam di Malaysia, International Journal of Islamic and Civilizational Studies, $\mathrm{h}$. 86 , 